\title{
The attention of students during physical education class based on academic performance La atención de los estudiantes durante la clase de educación física basada en el rendimiento académico

\author{
*Jorge Manuel Folgado dos Santos, *João Manuel Patricio Duarte Petrica, *João Júlio Matos Serrano, *Marco \\ Alexandre da Silva Batista, ${ }^{*}$ Samuel Alexandre de Almeida Honório, ${ }^{* *}$ Luis Alberto Coelho Rebelo Maia \\ *Polytechnic Institute of Castelo Branco (Portugal), **Beira Interior University (Portugal)
}

\begin{abstract}
Attention is an important variable that can dictate the success and failure of an activity or task. This variable is characterized by the ability to direct cognitive resources to a given situation. The purpose of this research was to find patterns in the students' attention profiles, according to their academic achievement, during the physical education class and in different sports. We used the ATEST-EF questionnaire (Petrica, 2010) in which students had to answer the question «What were you thinking the moment you heard the signal?»

The study involved 156 students from the $3^{\text {th }}$ cycle of basic education, aged between 12 and 16 years old $(\bar{X}=14,7 \pm 1,3)$ evaluated in four different sports taught in the discipline of physical education (athletics, gymnastics, basketball and football), and in four moments of the class. Considering our variables, we used Chi-Square and Kruskal-Wallis statistical tests. The results show that task attendance holds the highest percentage values throughout the class in relation to the remaining categories, regardless of their academic performance and sport, but we observed that students with satisfactory and good academic performance have more stable values of attention regarding the students with less academic performance. We found statistical significance at the end of the class between students with good academic performance and affective attention, and among students with lower academic performance and attention to other things. Subsequently, we used the same classification to compare the profiles of attention among the four mentioned sports. We observed some patterns between team and individual sports, but did not find statistically differences, however the results suggest a positive relationship between attention and academic performance.
\end{abstract}

Key words: Academic performance, Attention, Parts of class, Physical Education.

Resúmen: La atención es una variable importante que puede dictar el éxito y el fracaso de una actividad o tarea. Esta variable se caracteriza por la capacidad de dirigir recursos cognitivos a una situación dada. El propósito de esta investigación fue encontrar patrones en los perfiles de atención de los estudiantes, de acuerdo con sus logros académicos, durante la clase de educación física y en diferentes deportes. Utilizamos el cuestionario ATEST-EF (Petrica, 2010) en el que los estudiantes tenían que responder la pregunta «¿Qué estaba pensando en el momento en que escuchó la señal?» En el estudio participaron 156 estudiantes del tercer ciclo de educación básica, con edades comprendidas entre 12 y 16 años $(=14,7 \pm 1,3)$ evaluados en cuatro deportes diferentes que se imparten en la disciplina de educación física (atletismo, gimnasia, baloncesto y fútbol), y en cuatro momentos de la clase. Considerando nuestras variables, utilizamos las pruebas estadísticas Chi-Square y Kruskal-Wallis. Los resultados muestran que la asistencia a las tareas tiene los valores porcentuales más altos en toda la clase en relación con las categorías restantes, independientemente de su rendimiento académico y deporte, pero observamos que los estudiantes con un rendimiento académico satisfactorio y bueno tienen valores de atención más estables con respecto a los estudiantes con Menos rendimiento académico. Encontramos significación estadística al final de la clase entre estudiantes con buen rendimiento académico y atención afectiva, y entre estudiantes con bajo rendimiento académico y atención a otras cosas. Posteriormente, utilizamos la misma clasificación para comparar los perfiles de atención entre los cuatro deportes mencionados. Observamos algunos patrones entre el equipo y los deportes individuales, pero no encontramos diferencias estadísticas, sin embargo, los resultados sugieren una relación positiva entre la atención y el rendimiento académico.

Palabras clave: rendimiento académico, atención, partes de la clase, educación física.

\section{Introduction}

Today the practice of regular physical activity is already recognized as an enhancer of a healthier lifestyle where the practice contributes to the development of physical (Calahorro-Cañada, Torres-Luque, Lopez-Fernandez \& Carnero, 2016), psychological (Cotman, Berchtold \& Christie, 2007) and social components (Wigfield, Cambria, \& Eccles, 2012).

According to Chaddocka et al. (2010) sport's practice, especially in young adolescents, have a positive relationship with the development of several psychological capabilities such as the growth of nerve cells (Bellies, Figueiredo, Aurelio \& Grindstone 2018), better vascularization and neural activity (Bullitt et al., 2009), volume of brain tissue (Kamijo, et al., 2011), among others.

Fecha recepción: 11-10-19. Fecha de aceptación: 08-01-20 Jorge Manuel Folgado dos Santos

jorgesantos@ipcb.pt
Attention is an important cognitive ability, which can dictate the success or failure during the activities of our daily life. Fehmi and Shor (1990) indicate that this component is characterized by the ability to develop our brain resources for a given situation. So physical activity can and should be practiced from an early age, since children are more receptive to outside stimulus, as a result of practice, the body will have a better development as well as improve their attention, concentration, information storage and processing, among others, which will enhance their academic performance (Budde, Voelcker-Rehage, Pietrabyk-Kendziorra, Ribeiro \& Tidow, 2008; Trudeau \& Shepard, 2008; Bullitt et al, 2009; Pesce, Crova, Cereatti, Casella \& Bellucci, 2009; Chaddocka et al., 2010; Wolf, Batista \& Delgado, 2015).

The academic performance has been the subject of several investigations. For example, a systematic review conducted by Peralta, et al. (2014) identifies several studies in physical education and where positive associations were found 
in both boys and girls (Martins, Marques Diniz \& Costa, 2010; Ardoy, et al, 2014). Furthermore, a more recent systematic review about the influence of physical activity on academic achievement (Marques, Gomez, Martins, Catunda \& Sarmento, 2017). It shows that, in general, the researchers found a positive correlation between the academic achievement and physical activity (Batista, Lercas, Ferreira, Taborda \& Faustino, 2016; Marques, Gomez, Martins, Catunda \& Sarmento, 2017; Barrigas, Figueiredo, Aurelio \& Grindstone 2018). A review of Santana et al. (2017) is more specific, the authors found articles that seek to associate more particular components of the training or physical activity to academic performance, such as cardiorespiratory function, flexibility and body composition (Esteban-Cornejo et al., 2014; Torrijos-Nino et al., 2014; Garcia-Hermoso 2016). They also found a positive association between physical activity and the previously described indicators, consistent with the literature cited in this paragraph.

From a developmental perspective, children between 3 and 5 years should carry out activities that stimulate their sensory and motor systems. Subsequently there is an evolution from 5 to 10 years where coordination and motor control allow a better development for learning new and more complex motor skills. Children need to be stimulated with appropriate/adapted exercises, where the practice has many positive effects. In relation to motor skills, these are being acquired and supporting the learning of more complex skills in exercises/situations whose attentional levels make a difference to the acquisition, success and decrease assimilation time (Ladewig, 2017).

Attention has an important role in the teaching/learning process, as shown on investigations such as Petrica and Tavares (1999), Petrica (2003), Santos (2009), Santos et al, (2020) that measured and plotted attentional profiles during physical education classes. We also found studies with an emphasis on attentional focus, such as Tsetseli, Zetou, Vernadakis and Mountaki (2018) who studied the attentional focus of young people while practicing tennis. They found that students who received feedback from external nature had better results than students who received internal feedbacks. In addition to the internal and external type of feedback (attentional focus directed to inner feelings and thoughts versus attentional focus on external stimuli to the body itself, such as the movement of teammates), there are two types concerning the number of stimuli that can be assimilate simultaneously. In the case of an individual being able to process one or two stimuli at the same time, it is considered that he has a narrow attention, when you can perceive and process more than two stimuli, it is considered that has a wide attention (Nideffer \& Sagal, 2010; Santos, Petrica \& Maia, 2019; Weinberg \& Gould, 2019).

According to this, it's our intention to investigate whether there is a positive association between academic performance of students and their attention. For this purpose we traced an attentional profile based on the academic performance of students during a physical education class, and then check for patterns according to the different sports covered in those classes.

\section{Methodology}

The variables and procedures used are consistent with the qualitative and cross typology because we only held data collection once.

Our sample consisted of 156 students of the Institute Vaz Serra in Cernache do Bonjardim, aged between 12 and $16(\bar{x}$ $=14.7 \pm 1.3)$ where 84 were female (53.8\%) and the remaining 72 were males $(46.2 \%)$. They all attend the 3 rd cycle $\left(7^{\text {th }}, 8^{\text {th }}\right.$ or $9^{\text {th }}$ grade), and were evaluated in the practice of one of four sports (Athletics, Gymnastics, Basketball and Football) which gave us a total of 624 observational units that gave 2496 statistical data.

\section{Procedures}

Before beginning the research, both the school and the student's parents gave the authorization so that their students could be part of our study.

To be able to achieve our goal we used the ATEST-EF (Petrica, 2010), with procedures already applied by other authors to analyze the attention and the teaching/learning process (Petrica, 2003; Santos, 2009; Santos, Petrica \& Maia, 2019), which allowed us to evaluate students at several times in the class, in a quick way and without changing the proper functioning of the class.

To determine the attentional profiles of students and their academic performance, we used the same three categories that Santos (2009), where the income is obtained from the mean of all school subjects in the $3^{\text {rd }}$ period. The classification is «weak»(mean values less than 3 ), satisfactory (mean values between 3 and 3.95) and good (mean values higher than 4).

The ATEST-EF is a questionnaire that allows us to know in a simple and quick way, what students are thinking. They were distributed by students and procedures explained to them before the beginning of the class. In short, when they heard the beep (previously known), they would have to register one of several options to the question «What were you thinking when you heard the signal?» For the data collection, Atest-EF was applied in four classes of Athletics, Gymnas- tics, Football and Basketball, at certain moments of the class (initial part, main part and final part). At certain moments, it was issued by a non-participant in the class, a sound signal previously known to the students (Fox whistle), and immediately after hearing the signal, students would have to move to a predetermined location where they would

\begin{tabular}{|c|c|c|c|}
\hline Attentional variables & Level & Sub-variable & Item \\
\hline Attention to the task & 5 & $\begin{array}{l}\text { To be performed } \\
\text { In realization } \\
\text { Fulfilled }\end{array}$ & $\begin{array}{l}\text { What am I going to do? } \\
\text { What am I doing? } \\
\text { What I did. }\end{array}$ \\
\hline $\begin{array}{l}\text { Attention to the } \\
\text { behaviour }\end{array}$ & 4 & $\begin{array}{l}\text { Behaviour of the: } \\
\text { Teacher; } \\
\text { Colleagues. }\end{array}$ & $\begin{array}{l}\text { What the teacher was doing. } \\
\text { What my colleagues were doing. }\end{array}$ \\
\hline $\begin{array}{l}\text { Attention to the } \\
\text { information }\end{array}$ & 3 & $\begin{array}{l}\text { Listening } \\
\text { Relate to. } \\
\text { Understanding } \\
\end{array}$ & $\begin{array}{l}\text { What the professor was saying. } \\
\text { What my colleague said. }\end{array}$ \\
\hline Affective attention & 2 & $\begin{array}{l}\text { colleagues } \\
\text { teachers } \\
\text { friends } \\
\text { Family }\end{array}$ & $\begin{array}{l}\text { In my colleague } \\
\text { In my teacher } \\
\text { In my friends } \\
\text { In my family }\end{array}$ \\
\hline Attention outside the task & 1 & $\begin{array}{l}\text { In class } \\
\text { Outside the class }\end{array}$ & $\begin{array}{l}\text { What my colleague did to me. } \\
\text { What am I going to do to my colleague. } \\
\text { What am I going to do on break. } \\
\text { In a computer game. }\end{array}$ \\
\hline Attention in other things & 0 & Others & Another thing. What? \\
\hline
\end{tabular}


have to mark with an (x) the option that faithfully catalogued what they were thinking the moment they heard the signal and immediately returned to their normal activity.

\section{Statistical procedures}

All analyzes were performed using SPSS, version 25.0 (IBM, Chicago, Illinois, USA). Descriptive statistics (mean \pm standard deviation), Chi-Squared $(\div 2)$ and Kruskal-Wallis tests were made, assuming a $5 \%$ error probability ( $\mathrm{p} \mathrm{d} \gg 0.05$ ). To understand which groups showed statistical differences we used the residual adjustments, that according to Sharpe (2015) the value is significant when the value is equal to or greater than 1.96 .

\section{Results}

Now we present the descriptive values of the number of students, considering their academic performance. The number of students with academic performance «satisfactory» $(\mathrm{N}=372 ; 59.6 \%, 1488$ responses) is far greater than the other categories, corresponding to more than half of the sample. With «good» academic achievement we had 160 students (25.6\%; 640 responses) and finally 92 with «weak» academic performance (14.7\%; 368 replies).

Subsequently, we cross the attentional variables with the categories of academic achievement. In students with weak academic achievement that corresponds to the lowest percentage of our sample we observed on table 1 that throughout the class students are paying attention to the task (AT), followed by attention to the behaviour $(\mathrm{AB})$ with a higher percentage value than attention to information (AI) only in the fundamental part of the class (2nd and 3rd Signal). In terms of affective attention (AA) the percentage increases in the 1st signal to the 2 nd signal and then decreases to the $3 \mathrm{rd}$ signal and returns to increase in the end of the class. The remaining two variables related to external things of the class (Attention outside the task and attention in other things), have lower percentage values throughout the lesson. In the end of the class there were more students «distracted» then in the rest of the class.

\begin{tabular}{|c|c|c|c|c|c|c|c|c|}
\hline & & & & & & & & \\
\hline & $\mathrm{N}$ & $\%$ & $\mathrm{~N}$ & $\%$ & $\mathrm{~N}$ & $\%$ & $\mathrm{~N}$ & $\%$ \\
\hline $\mathrm{AB}$ & 16 & $\begin{array}{ll}17.4 \\
\end{array}$ & 25 & 27.2 & 23 & 25 & 15 & 16.3 \\
\hline AI & 19 & 20.7 & 11 & 12 & 10 & 10.9 & 17 & 18.5 \\
\hline AT & 41 & 44.6 & 41 & 44.6 & 47 & 51.1 & 36 & 39.1 \\
\hline AA & 10 & 10.9 & 14 & 15.2 & 7 & 7.6 & 10 & 10.9 \\
\hline AOT & 2 & 2.2 & 0 & 0 & 4 & 4.3 & 4 & 4.3 \\
\hline AoT & 4 & 4.3 & 1 & 1.1 & 1 & 1.1 & 10 & 10.9 \\
\hline
\end{tabular}

Like in the previous situation, we present below the respective absolute values and percentages (Table 2) of all attentional categories of students with satisfactory academic achievement in the different signals. We note that the category that stands out the most is the attention to the task (AT), which has always been increasing until the end of the fundamental part ( $3^{\text {rd }}$ Signal). In the case of attention to information (AI) and the attention to the behaviour (AB), these had approximate percentages, with little fluctuation, but denote that attention to information (AI) only decreases from the 1 st to $3^{\text {rd }}$ signal. The remaining variables show small percentages and in all of them there is an increase on the 4 th signal.
Table 3

Frequency and percentage of students' attentional profile with satisfactory academic performance according to signals.

\begin{tabular}{ccccccccc}
\multicolumn{1}{l}{ performance according to signals. } \\
\multicolumn{1}{c}{ 1st Signal } & \multicolumn{2}{c}{ 2nd Signal } & \multicolumn{2}{c}{ 3rd Signal } & \multicolumn{2}{c}{ 4th Signal } \\
& $\mathrm{N}$ & $\%$ & $\mathrm{~N}$ & $\%$ & $\mathrm{~N}$ & $\%$ & $\mathrm{~N}$ & $\%$ \\
\hline $\mathrm{AB}$ & 63 & 16.9 & 74 & 19.9 & 68 & 18.3 & 69 & 18.5 \\
$\mathrm{AI}$ & 120 & 32.3 & 70 & 18.8 & 57 & 15.3 & 74 & 19.9 \\
$\mathrm{AT}$ & 153 & 41.1 & 203 & 54.6 & 217 & 58.3 & 162 & 43.5 \\
$\mathrm{AA}$ & 22 & 5.9 & 12 & 3.2 & 20 & 5.4 & 23 & 6.2 \\
$\mathrm{AOT}$ & 12 & 3.2 & 9 & 2.4 & 7 & 1.9 & 27 & 7.3 \\
$\mathrm{AoT}$ & 2 & 0.5 & 4 & 1.1 & 3 & 0.8 & 17 & 4.6 \\
\hline
\end{tabular}

The results of students with good academic achievement (Table 3) reveal a high level of attention to the task (AT) that is distinguishable from the other attentional categories, such as the remaining sample. This attention (AT) obtained values almost «stable» throughout the physical education class, contrasting slightly when compared to the previous ones. The attention to the behaviour (AB) shows an increased percentage to the 2 nd signal but has a decrease until the end of class. The attention to information (AI) and affective attention (AA) have a similar variation, both begin to decrease in the initial part to the fundamental part and slightly increase until the end of the class. Attention outside the task (AOT) and attention on other things (AoT) had very low percentages throughout the lesson and values have little variance

\begin{tabular}{|c|c|c|c|c|c|c|c|c|}
\hline \multicolumn{9}{|c|}{$\begin{array}{l}\text { Frequency and percentage values of students' attentional profile with good academic } \\
\text { achievement in the different signals. }\end{array}$} \\
\hline & \multicolumn{2}{|c|}{ 1st Signal } & \multicolumn{2}{|c|}{ 2nd Signal } & \multicolumn{2}{|c|}{ 3rd Signal } & \multicolumn{2}{|c|}{ 4th Signal } \\
\hline & $\mathrm{N}$ & $\%$ & $\mathrm{~N}$ & $\%$ & $\mathrm{~N}$ & $\%$ & $\mathrm{~N}$ & $\%$ \\
\hline $\mathrm{AB}$ & 22 & 13.8 & 39 & 24.4 & 35 & 21.9 & 29 & 18.1 \\
\hline $\mathrm{AI}$ & 33 & 20.6 & 18 & 11.3 & 21 & 13.1 & 19 & 11.9 \\
\hline AT & 80 & 50 & 84 & 52.5 & 80 & 50 & 79 & 49.4 \\
\hline $\mathrm{AA}$ & 19 & 11.9 & 9 & 5.6 & 17 & 10.6 & 24 & 15 \\
\hline AOT & 4 & 2.5 & 6 & 3.8 & 5 & 3.1 & 7 & 4.4 \\
\hline AoT & 2 & 1.3 & 4 & 2.5 & 2 & 1.3 & 2 & 1.3 \\
\hline
\end{tabular}

To find statistical differences we used the Chi-Squared and Kruskal-Wallis tests. Except for the 4th signal, the remaining variables did not meet the conditions for the realization of the Chi-Squared, therefore they are presented alternatively the Kruskal-Wallis test.

Therefore, we started by analyzing the relationship between the categories and the attention on the whole sample, according to their academic performance in different signals. The results show statistically significant differences in some of the lesson times which are presented below (Table 4).

\begin{tabular}{|c|c|c|c|c|c|c|c|}
\hline \multicolumn{2}{|c|}{ 1st Signal } & \multicolumn{2}{|c|}{ 2nd Signal } & \multicolumn{2}{|c|}{ 3rd Signal } & \multicolumn{2}{|c|}{ 4th Signal } \\
\hline $\begin{array}{c}\text { Chi- } \\
\text { Squared } \\
(? 2)\end{array}$ & $\begin{array}{c}\text { Kruskal- } \\
\text { Wallis }\end{array}$ & $\begin{array}{c}\text { Chi- } \\
\text { Squared } \\
(? 2)\end{array}$ & $\begin{array}{c}\text { Kruskal- } \\
\text { Wallis }\end{array}$ & $\begin{array}{c}\text { Chi- } \\
\text { Squared } \\
(? 2)\end{array}$ & $\begin{array}{l}\text { Kruskal- } \\
\text { Wallis }\end{array}$ & $\begin{array}{c}\text { Chi- } \\
\text { Squared } \\
(? 2)\end{array}$ & $\begin{array}{l}\text { Kruskal- } \\
\text { Wallis }\end{array}$ \\
\hline $.006 *$ & $.004 *$ & $.001 *$ & $.006 *$ & .317 & .136 & $.001 *$ & $.023 *$ \\
\hline
\end{tabular}

From the results of statistical tests and the residual adjustments we found statistically significant differences in the 4th signal between students with good academic performance and affective attention (AA; residual adjustments = 2.5 ) and among participants with weak academic achievement and attention to other things (AoT; residual adjustments $=2.8$ ).

On the $3^{\text {rd }}$ signal there's no significant differences $(\mathrm{p}>$ .05 ), and on signals 1 and 2 the results of Chi-Squared did not fulfil all the assumptions, that is, the expected proportion of cells exceeds $20 \%$ ( 1 st signal: $27.8 \%$; 2 nd signal; $22.2 \%$ ). However, as the value of the Kruskal-Wallis test has approximated significant to the Chi-Squared value, we decided to accept these two results as good indicators of the existence 
of statistically significant differences between attention and academic performance in students. With the residual adjustments the differences are on the 1st signal, among students with weak academic performance and attention to other things (AoT; residual adjustments $=2.6$ ) and on the 2 nd signal between students with good academic achievement and affective attention (AA; residual adjustments $=3.9$ ).

Then we will conduct the same process to verify the existence of attentional patterns in the several sports taught in physical education class, depending on their income (Charts 1,2 and 3).
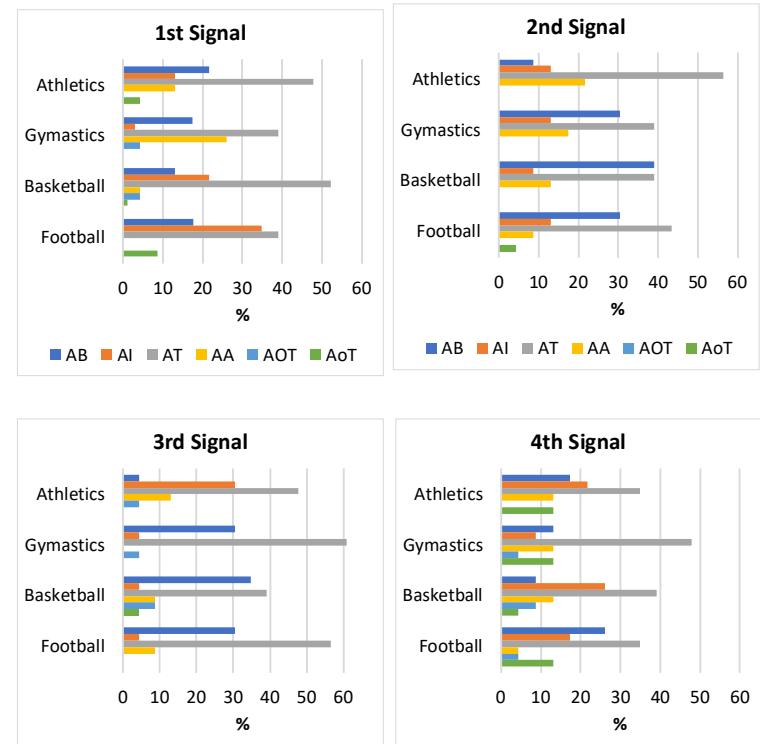

$\because \mathrm{AB} \backsim \mathrm{Al} \backsim \mathrm{AT} \backsim \mathrm{AA} \backsim \mathrm{AOT} \backsim \mathrm{AOT}$

$\llbracket \mathrm{AB} \backsim \mathrm{Al} \backsim \mathrm{AT} \backsim \mathrm{AA} \backsim \mathrm{AOT} \backsim \mathrm{AOT}$

Graphic 1 - Attentional profile of students with weak academic performance in different sports. Attention to the behaviour (AB), attention to information (AI), attention to task (AT), emotiona attention (AA), attention off the task (AOT) and attention to other things (AoT).

Students with weak academic achievement shows that they are essentially attentive to the class and its associated components, whereby the percentage values of attention to the task (AT), attention to information (AI) and attention to behaviour $(\mathrm{AB})$ are higher in relation to other categories. The amount of attention to the task (AT) is the highest in all sports evaluated. At the beginning of the class, students with weak academic performance in the practice of team sports have more attention to information (AI) than pupils practicing the individual sports, however attention to behaviour (AB) and affective attention (AA) have values higher in individual sports than in collective.

Expose in chart 1 are the attentional profiles of students with weak academic performance in different moments and different sports. At the beginning of the class the students with weak performance, evaluated during the practice of athletics are particularly attentive to the task and behaviour. In the main part of the class there has been an increased attention to the task (AT) as opposed to attention to the behaviour (AB). The percentage levels of affective attention (AA) rise at the end of the class, the attention to the task (AT) decreases and there is an increase on attention to behaviour (AB).

On gymnastics, students with weak performance have more attention to the task (AT) throughout the lesson, with reduced percentages on attentional categories that relate negatively to the teaching/learning process (Attention off task and attention to other things).

The affective attention (AA) has high values at the first signals in relation to the $3 \mathrm{rd}$ and 4 th signals. The percentage values of attention to information (AI) are relatively stable throughout the lesson and attention to behaviour (AB) increases from the beginning to the end of gymnastics class. In basketball students show to be aware of the task, which have low values of inattention (attention off the task and attention to other things). The initial and final part of the class have values of attention to the behaviour (AB) lower than in the fundamental part of the class. On football, attention to the task (AT) is the attentional focus with the highest percentage over the class.
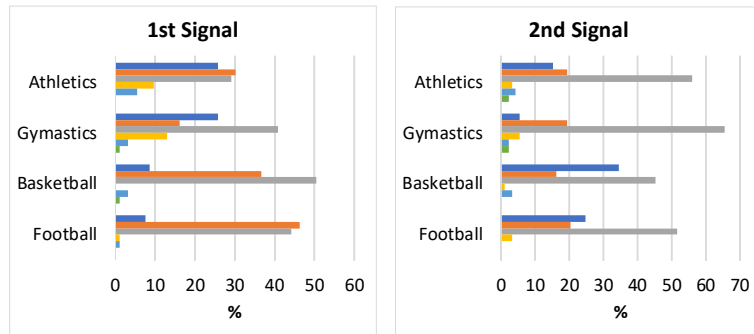

$\square \mathrm{AB} \square \mathrm{Al} \square \mathrm{AT} \square \mathrm{AA} \backsim \mathrm{AOT} \square \mathrm{AOT}$
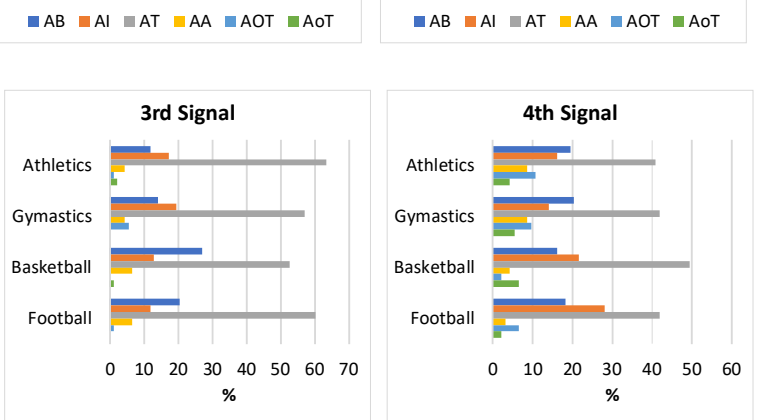

$\because \mathrm{AB} \backsim \mathrm{Al} \backsim \mathrm{AT} \backsim \mathrm{AA} \backsim \mathrm{AOT} \backsim \mathrm{AOT}$

$\because \mathrm{AB} \backsim \mathrm{Al} \backsim \mathrm{AT} \backsim \mathrm{AA} \backsim \mathrm{AOT} \backsim \mathrm{AOT}$

Graphic 2 - Attentional profile of students with satisfactory performance in different sports. Attention to the behaviour (AB), attention to information (AI), attention to task (AT), affective attention (AA), attention off the task (AOT) and attention to other things (AoT).

Students evaluated on athletics with satisfactory academic achievement begin with more attention to information (AI), attention to task (AT) and attention to behaviour (AB), respectively. From the fundamental part (2nd signal) students begin to focus more on the task than in the other variables, at the end of the class the values of attention to behaviour $(\mathrm{AB})$ and attention to information $(\mathrm{AI})$ begin to increase. We observed that the attentional profile of students evaluated on gymnastics have many similarities to the profile of athletics students in the 2nd signal. «Gymnasts» have higher percentages of attention to the task (AT) than students of athletics, and the opposite happens at the end of the key part (3rd signal).

In collective sports (basketball and football) students with satisfactory performance show a very similar attentional profile throughout the lesson, where attention to the task (AT), attention to information (AI) and attention to behaviour (AB) stand out. Note an exception in the beginning of the class where students of football are more attentive to information (AI) than to the task.

As in previous charts, we can see some similar traits among the team sports profiles (basketball and football) and the individual ones (athletics and gymnastics). We denote 

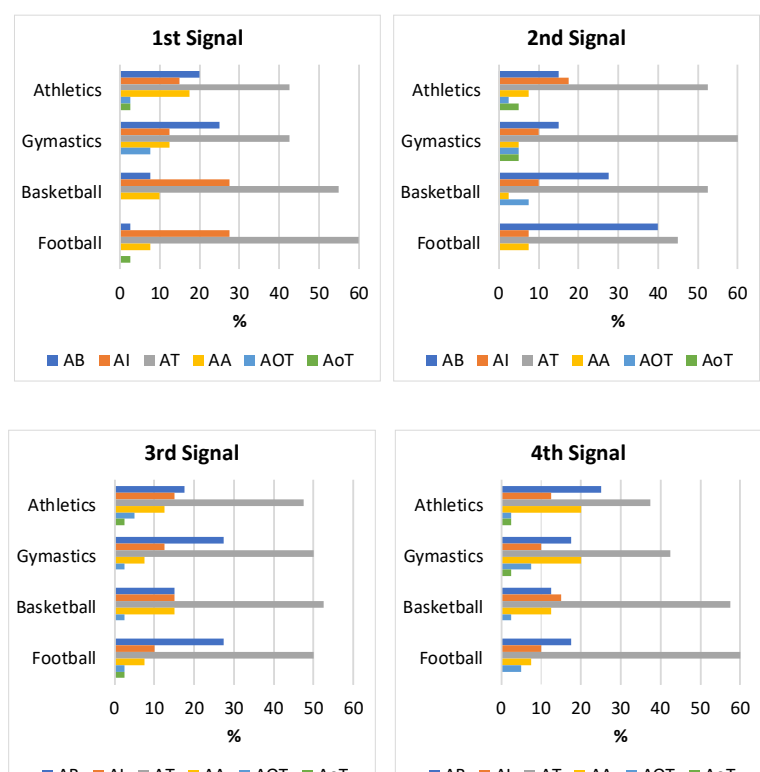

$\square \mathrm{AB} \backsim \mathrm{Al} \backsim \mathrm{AT} \backsim \mathrm{AA} \backsim \mathrm{AOT} \backsim \mathrm{AOT}$

$\because \mathrm{AB}=\mathrm{Al}=\mathrm{AT} \sim \mathrm{AA} \sim \mathrm{AOT} \sim \mathrm{AOT}$

Graphic 3 - Attentional profile of students with good performance in different sports. Attention to the behaviour $(\mathrm{AB})$, attention to information $(\mathrm{AI})$, attention to task (AT), affective attention (AA), attention off the task (AOT) and attention to other things (AoT)

that students with good academic achievement, evaluated during the practice of athletics and gymnastics, are mainly attentive to the task (AT) and to behaviour (AB), at the beginning and end of the class. The basketball and football students however have higher percentage values in attention to the task (AT) and attention to information (AI) than in individual sports.

During the main part of the class students of team sports have more attention to the task (AT) and attention to behaviour (AB) instead of attention to information (AI). Students of gymnastics and athletics are more focused on the task and behaviour during almost all signals except signal 2. On the end of the class we can see higher levels of affective attention (AA) than in the rest of the class.

Its observable that there are some traces in attentional profiles depending on their academic performance, so we have verified the existence of statistically significant differences on different sports, where we found only differences in football (1st signal) and gymnastics (2nd signal), as shown in table 5 .

Table 6

Values $8 \mathrm{f}$ the Chi-Squared and Kruskal-Wallis at different times on the four sports practiced.

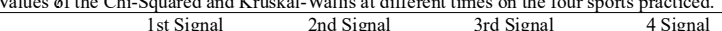

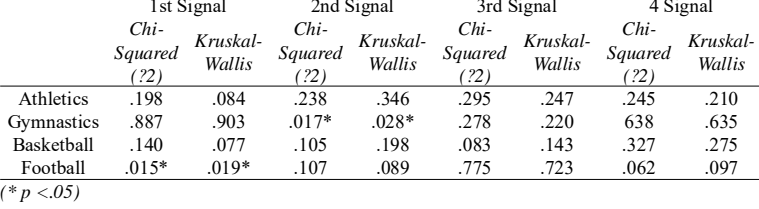

With these results we search for where the differences are, from the residual adjustments on their signals. In the 1st signal in football are the differences in students with weak academic performance and attention to other things (AoT; residual adjustments $=2.6$ ) in satisfactory academic performance and attention to information (AI; residual adjustments $=2.0$ ) and attention to other things (AoT; residual adjustments $=2.1$ ) on good academic achievement and affective attention (AA; residual adjustments $=2.3$ ).

In the case of the 2 nd signal on gymnastics, differences occur in weak academic performance and attention to behaviour $(\mathrm{AB}$; residual adjustments $=3.1)$ as well as attention to the task (residual adjustments $=2.2$ ) and affective attention (AA; residual adjustments $=2.1$ ). We have also found differences in students with satisfactory academic achievement and attention to behaviour (AB; residual adjustments $=2.9$ ).

\section{Discussion of Results}

Our results show that students during physical education classes, are especially attentive to the task, these values will meet studies like Petrica (2003), Santos (2009) and Santos et al. (2019) which also found that attention to the task is the one that stands out more in comparisson to the remaining attentional categories.

We denote although the percentage values of attention to the task (AT) are higher on students with satisfactory/ good academic achievement, than on students with lower academic performance. This is consistent with the results of Wolf, Batista and Delgado (2015) and Batista, Lercas, Ferreira, Taborda and Faustino (2016) to conclude that there is a positive trend between academic performance and the number of hours of sports practice. However students with weak academic performance report being more inattentive to class issues and the teacher, in relation to students with higher performance, whose percentages for the attention outside the task and in other things are low.

The pace of learning is variable from individual to individual, so that the students' attention to the contents taught is indispensable, with time and experience they can understand and acquire new skills, and attention will be one of the factors that will dictate if the development is faster and better (Ladewig, 2017). It is also necessary that the teacher can create and adapt their ways of teaching to their target audience, not only to captivate their attention and promote their development, but also to effectively give more motor engagement time as possible, to contribute to a good physical, psychological and social development, as is also evidenced in studies of Chaddocka, et al. (2010), Erwin, Fedewa and Ahn (2012), Ardoy et al. (2014).

In terms of differences between groups, unlike Santos (2009), we detected statistically significant differences on the final part of the class (4th signal), among students with good academic performance and affective attention (AA), and among students with lower academic achievement and attention to other things (AoT). For the 1st and 2nd signals the assumptions were not fully met (number of expected cells is higher then $20 \%$ ), but was not far beyond what would be the desirable value, we will accept these results as indicators to investigate further in the future. The differences are in the initial and fundamental part of the class, between students with weak academic performance and the attention to other things (AoT) and affective attention (AA).

On attentional profiles of the different sports we found some interesting similarities, with some attentional patterns between the two individual sports and the two team sports. This leads us to think about the strategy that is used by the teacher, taking into account the waiting times that can disperse students attention more of the class issues because they are not in practice, which reduces the motor time com- 
mitment and this may be an explanation for our differences in students with weak academic performance with attention to other things (AoT; residual adjustments $=2.8$ ).

The results suggest that the affective attention (AA) has significant results on students with good academic performance (residual adjustments $=3.9$ ) and the students during this exercise with weak academic performance (residual adjustments $=2.1$ ), however the affective attention (AA) is an attentional category that can create some doubts, as previously mentioned the practice of physical activity promoted in physical education classes also develops the socioaffective component, however if this is not directed to the class content then the students are distracted.

We tried to find differences between attentional categories according to academic achievement on four different sports, the statistical tests show differences in the gymnastics (2nd signal) and football (1st signal), however we can only take these results as good indicators of the existence of statistically significant differences because the expected number of cells are exceeded (61.1\%).

\section{Conclusions and Recommendations}

The attention of students during physical education class is focused mainly on the task and less focused on things outside the class regardless of their academic performance, but attention values of students with satisfactory/good academic achievement have an attentional profile more directed to improve the teaching/learning process.

The differences found are good indicators that students with a satisfactory and good academic achievement reveal attentional levels of attention to the task (AT) more stable, than students with weak academic performance. In this way we remember the importance of improving the forms of intervention of teachers in physical education classes to develop strategies to give more time to students in order to increase motor commitment. One way to monetize the time it is the quality and quantity of information provided to students, «using» students to help on organization of the lecture material, between these and others, it is possible to adapt certain aspects to retain students' attention (Grube, Ryan, Lowell, \& Stringer, 2018).

In attentional profiles, when comparing the sports we can observe an attentional pattern that may result from the context and teaching strategies. As is the case with attention to information (AI) on the 1st signal, whose percentages are higher on team sports than on individual ones, as it will be when the teacher explains the lesson objectives and the necessary information, this factor seems to outstand on team sports, perhaps because these sports have many group exercises that depending on the amount of information requires more time to explain, and therefore is required more attention from the students.

Similarly there has been generally a high percentage of attention to the behavior (AB), especially in the key part of the class, perhaps because students have already begun to practice and also focus their attention on the behavior of their colleagues.

Thought is a complex variable to analyze and therefore «questioned students» to know exactly what catches their attention. Unfortunately we did not find many recent studies that have been used the same procedures so we can make more comparisons or establish more relationships, however, we recommend a sample increase and methodological replication of the study so that we can take more concrete inferences face the theme.

\section{Author Information}

*Jorge Manuel Folgado dos Santos, *João Manuel Patricio Duarte Petrica, *João Júlio Matos Serrano, *Marco Alexandre da Silva Batista, *Samuel Alexandre de Almeida Honório, **Luis Alberto Coelho Rebelo Maia

*SHERU (Sport, Health and Exercise Research Unit), Polytechnic Institute of Castelo Branco ** Beira Interior University, Portugal - Center in Sports Sciences, Health Sciences and Human Development (CIDESD)

\section{References}

Ardoy, D., Rodriguez-Fernandez, J., Jiménez-Pavon, D., Castillo, R., Ruiz, JR. \& Ortega, F. (2014). The Physical Education Improves trial adolescents' cognitive performance and academic achievement: the EDUFIT study. Scandinavian Journal of Medicine \& Science in Sport, 12, 5261

Bellies, C., Figueiredo, N., Aurelio H. \& Grindstone, A. (2018). Physical Education, Physical Fitness and Academic Performance. Newsletter Portuguese Society of Physical Education, 41, 67-82.

Baptist, A.S., Lercas, A.J., Ferreira, D., Taborda, B. \& Faustino, A.J. (2016). Academic Performance Evaluation in Volume function oriented and Body Coordination Quotient Children 1st cycle. E-handball: Journal of Sport Science, 12(3), 185-194.

Budde, H., Voelcker-Rehage, C., Pietrabyk-Kendziorra, S., Ribeiro, P. \& Tidow, G. (2008). Acute coordinative exercise Improves attentional performance in adolescents. Neuroscience Letters, 441(2), 219-223

Bullitt, E., Rahman, F.N., Smith, J.K., Kim, E., Zeng, D., Katz, L.M. \& Marks, B.L. (2009). The effect of exercise on the brain vasculature of healthy subjects aged visualized by the MR Angiography. American Journal of Neuroradiology, 30, 1857-1863.

Calahorro-Canada, F., Torres-Luque, G., Lopez-Fernandez, I. \& Carnero, E.A. (2016). Physical Education is an effective way to Increase physical activity in children with lower cardiorespiratory fitness? Scandinavian Journal of Medicine \& Science in Sport, 27(11), 1417-1422

Chaddocka, L., Erickson, K., Prakash, R.S., Kim, J.S., Voss, M., VanPatter, M. \& Kramer, A. (2010). The neuroimaging investigation of the association between aerobic fitness, hippocampal volume and memory performance in preadolescent children. Elsevier, 12, 172-183.

Cotman, C.W., Berchtold, N.C.\& Christie, L.A. (2007). Exercise builds brain health: key roles cascades of growth factor and inflammation. Elsevier, 30(9), 464-472.

Erwin, H., Fedewa, A. \& Ahn, S. (2012). Student Academic Performance Outcomess Classroom of Physical Activity Intervention: A Pilot Study. International Journal of Elec- 
tronic Elementary Education, 4(3), 473-487.

Cornejo-Esteban, I., Gonzalez-Tejero, M.C., Gomez-Martinez, D., Del Campo, J., Gonzalez-cock, A., Moledo-Padilla, C. \& Veiga, L.W. (2014). Independent and Combined Influence of the Components of Physical Fitness on Academic Performance in Youth. The Journal of Pediatrics, 165(2), 306-312.

Fehmi, L.G. \& Shor, S.B. (1990). Open Focus: The Attentional Foundation of Health and Well-being. In BJ Diehl, \& T. Miller, Moderne Suggestionsverfahren (pp. 425-437). USA: Springer.

Hermoso-Garcia, A. (2016). Aerobic capacity as a mediator of the influence of birth weight and school performance. Journal of Developmental Origins of Health and Disease, 7(4), 337-341

Grube, D., Ryan, S. Lowell, S. \& Stringer, A. (2018). Effective Classroom Management in Physical Education: Strategies for Beginning Teachers. Journal of Physical Education, Recreation \& Dance, 89(8), 47-52.

Kamijo, K., Pontifex, M.B., O’Leary, K.C., Scudder, M.R., Wu, C.T., Castelli, M.D. \& Hillman, C.H. (2011). The effects of physical activity an afterschool program on working memory in preadolescent children. Developmental Science, 14(5), 1046-1058.

Ladewig, I. (2017). The importance of attention in learning motor skills. Paulista journal Physics Education (suppl.3), 62-71.

Wolf, A., Batista, M. \& Delgado, S.C. (2015). Physical activity as a boosting factor of psychological variables and academic performance of primary school students. Latin American Journal of Psychology Ejercicio y el del Sport, 10(1), 85-93.

Marques, A., Gomez, F., Martinez, J., Catunda, R. \& Sarmento, H. (2017). Association between physical education, school-based physical activity, and academic performance: a systematic review. Straight(31), 316-320.

Martins, J., Marques, A., Diniz, J. \& Costa, F.C. (2010). Students lifestyle characterization of basic education with different levels of school performance. Newsletter Portuguese Society of Physical Education, (35), 87-98.

Nideffer, R.M., \& \& Sagal, M.S. (2010). Concentration and attention control training. In J. Williams, Sport Applied Psychology: Personal Growth to Peak Performance (6th ed, pp 382-403..). New York: McGraw-Hill Higher Education.

Peralta, M., Maurice, I., Lopes, M., Costa, S., Sarmento, H. \& Marques, A. (2014). The relationship between physical education and academic performance of adolescents: a systematic review. Journal of Child and Adolescent Psychology, 5 (2), 129-137.

Pesce, C., Crova, C., Cereatti, L., Casella, R. \& Bellucci, M. (2009). Physical activity and mental performance in preadolescents: Effects of acute exercise on free-recall memory. Mental Health and Physical Activity, 2(1), 16-2.

Petrica, J. (2003). The formation of Physical Education teachers: Analysis of visible and invisible dimension of education due to different models of preparation for practice. Vila Real: University of Tras-os-Montes and Alto Douro.

Petrica, J.M. \& Tavares, G.N. (1999). Study of attention in
Physical Education. Magazine Section of Physical Education, (1), 61-71.

Santana, D.C., Azevedo, L.B., Cattuzzo, M.T., Hill, J.O., Andrade, L.P. \& Prado, W.L. (2017). Physical fitness and academic performance in youth: A systematic review. Scandinavian Journal of Medicine \& Science in Sports, (27), 579-603.

Santos, J. (2009). The attention and school performance in physical education. Master's thesis, not published: University of Minho.

Santos, J.M., Petrica, J.M. \& Maia, L.A. (2019). Study of the attention and its importance in teaching / learning sports. Retos. Nuevas tendencias en Educación Física, Deporte y Recreación (36), 457 - 460.

Santos, J., Maia, L., Petrica, J., Serrano, J., Batista, M., \& Honorio, S. (2019). Attention in physical education classes: Differences between individual different modalities. Human Journal of Sport and Exercise, 14 (1 proc), S37 S46.

Santos, J., Maia, L., Petrica, J., Serrano, J., Batista, M., Lercas, A., \& Honório, S. (2020). Attention in physical education classes: Differences between colletive sports. Retos. Nuevas tendencias en Educación Física, Deporte y Recreación-(37), 129- 133

Sharpe, D. (2015). Your Chi-Square Test is statistically Significant: Now What? Practical Assessment, Evaluation \& Research, 20(8), 1-10.

Torrijos-Nino, C., Martinez-Vizcaíno, V., Brown-Guijarro, M.J., Garcia-Prieto, J.C., Arias Palencia, N.M. \& Sanchez-Lopez, M. (2014). Physical Fitness, Obesity, and Academic Achievement in Schoolchildren. The Journal of Pediatrics, 8, 104-109.

Trudeau, F. \& Shepard, R. (2008). Physical education, school physical activity, school sports and academic performance. International Journal of Behavioral Nutrition and Physical Activity, 10 (5), 1-12.

Tsetseli, M. Zetou, E., Vernadakis, N. \& Mountaki, F. (2018). The attentional focus impact on tennis skills' technique in 10 and under years old players: Implications for real game situations. Human Journal of Sport and Exercise, $13(2), 328-339$.

Weinberg, R.S. \& Gould, D. (2019). Concentration. RS Weinberg \& D. Gould, Foundations of Sport and Exercise Psychology (7th ed., Pp. 381-414). Champain: Human Kinetics.

Wigfield, A., Cambria, J. \& Eccles, J.S. (2012). Motivation, personality, and social development Within embedded contexts: An overview of self-determination theory. RM Ryan, The Oxford Handbook of human motivation (pp. 463-475). Oxford: Oxford Library of Psychology.

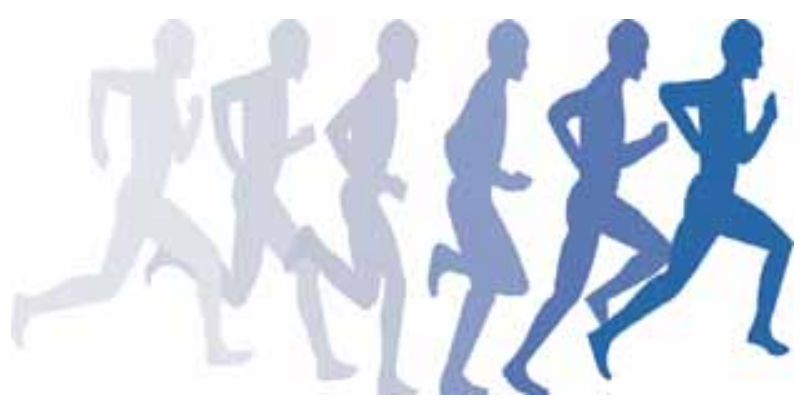

